\section{Influence of Zingiber officinale Extract on Push-Out Bond Strength of Glass-Fiber Post}

Tânia Mara da Silva, Virgílio Vilas Boas Fernandes Junior, Rosemary Soares de Santana, Renata Marques de Melo Marinho, Márcia Carneiro Valera, Eduardo Bresciani
Department of Restorative Dentistry, Institute of Science and Technology of São José dos Campos, UNESP - Universidade Estadual Paulista, São José dos Campos, SP, Brazil

Correspondence: Tânia Mara da Silva, Avenida Engenheiro Francisco José Longo, 777, Jardim São Dimas, 12245-000 São José dos Campos, SP, Brasil. Tel: +55-12-98101-0308. e-mail: taniamara.odonto@gmail.com
The aim of this study was to evaluate in vitro the influence of $20 \%$ glycolic ginger extract on the bond strength of glass-fiber post cemented with etch-and-rinse or self-etching resin cement. Forty-eight bovine roots were standardized $(17 \pm 0.5 \mathrm{~mm})$ and randomly divided into two groups, according to irrigant used during biomechanical preparation: $\mathrm{NaOCl}$ : $1 \%$ sodium hypochlorite and GEN: $20 \%$ glycolic ginger extract. Root canal was prepared and randomly assigned to one of two subgroups $(n=12)$, according to luting protocol: self-etching (RelyX U200) and etch-and-rinse (RelyX ARC). After $48 \mathrm{~h}$, the roots were sectioned perpendicularly ( 4 in cervical third and 3 in middle third) and submitted to push-out bond strength test (50 kgf load cell, $1.0 \mathrm{~mm} / \mathrm{min}$ ). Failure mode was analyzed in SEM and stereomicroscopy. Data were analyzed by three-way ANOVA and Tukey tests $(p<0.05)$. ANOVA revealed that there were no significant differences between U200 $(2.01 \pm 0.17) B$ and ARC $(1.93 \pm 0.12) B$ in GEN group, and at the cervical third for both irrigants, $2.69 \pm 0.16 \mathrm{~A}$ and $2.54 \pm 0.17 \mathrm{~A}$, respectively. Middle third showed lower bond strength than cervical third, regardless the irrigant. Overall, the cervical third regardless the irrigant employed and the association between $\mathrm{NaOCl}$ and $\mathrm{ARC}$, presented better adhesive performance.
Key Words: Zingiber officinale, luting agents, post, adhesion.

\section{Introduction}

The adhesion between tooth structure and adhesive cement is the result of physical and chemical interactions in dentin-cement interface (1). Various chemical substances are used as irrigation for root canal chemical-mechanical preparation, aiming for disinfection, dissolving pulp tissues and smear layer removal $(2,3)$. Among the marketed endodontic irrigating solutions, sodium hypochlorite, at different concentrations, is the most commonly used, fact supported by its dissolution capacity for necrotic tissue, antimicrobial $(2,3)$ and detergent actions, and low surface tension. Despite its positive properties, sodium hypochlorite is known to be highly irritant to periapical tissues at high concentrations (3).

Studies focusing on the use of phytotherapy substances against microorganism stand out in dental researches (4). Plant extracts are being evaluated as alternative irrigating solutions during endodontic therapy. Among those, ginger (Zingiber officinale) extract presents extraordinary property for eliminating reactive oxygen species, free radicals, peroxides, oxidants and it also acts on MMPs, especially MMP-9 (5) and MMP-2 (6). Zingiber officinale is native of Asia and contains vitamins, minerals and polyphenols, including the gingerol, shogaols, paradols and gingerone. Although these constituents compromise the anti-inflammatory and analgesic properties of ginger
$(3,7,8)$, previous studies have shown the effectiveness of ginger as intracanal medication on Enterococcus faecalis, Candida albicans and Escherichia coli $(8,9)$. On the other hand, ginger properties and applications still lack scientific explanations, once its physicochemical properties and its possible interference to adhesion of restorative materials are not fully known.

Some studies have reported that different endodontic irrigating solution might have a significant effect on the bond strength between adhesive and root dentin (10). The use of root intraradicular post, such as metallic, glass-fiber or carbon fiber posts, allows transferring of functional load from the restoration and root to dental structure, being this stress similarly distributed to the tooth (11). The use of glass-fiber post has become more popular than conventional metal posts (10), for ensuring favorable aesthetics, with no compromise to strength and long-term stability and for presenting elastic modulus similar to dentin (12). Those characteristics are enhanced when combined with resin cements, whose evolution takes relevance to resistance and adhesive interaction with the root dentin, factors important to the longevity of rehabilitation (13).

Many resin cements are available in dual-curing system (dual), in which the association of chemical activation and light-activation offers improvements in physical and mechanical properties when compared with single- 
activated (chemically or light) conventional cements. Dual-cured cements have advantages such as better adhesion, biocompatibility, improved mechanical property, and aesthetics (14); allowing a more simplified technique with less clinical time, minimizing possible failure on cementation $(15,16)$.

The aim of this study was to evaluate in vitro the influence of 20\% glycolic ginger extract on the bond strength of glass-fiber post using self-etching or etchand-rinse resin cement, according to root thirds. The null hypotheses tested were: (I) there is no significant difference in bond strength between ginger extract and sodium hypochlorite; (II) there is no significant difference in bond strength between evaluated resin cements; (III) there is no significant difference in bond strength between root thirds.

\section{Material and Methods}

\section{Sample Preparation}

The study was approved by the local Institutional Review Board (Protocol number 10/2015). Forty-eight bovine lateral incisors were selected, cleaned, immersed in deionized water, and frozen until use. Root with incomplete apex or with very wide foramen (over $40 \mathrm{LK}$ ) was excluded from the study.

Tooth crown was sectioned $2 \mathrm{~mm}$ from the cementoenamel junction with a diamond wheel (Dremel, Campinas, $\mathrm{SP}$, Brazil), in order to standardize root length at $17 \pm 0.5 \mathrm{~mm}$. Remnants of pulp tissue were removed with endodontic files (Kerr No.70, Maillerfer Instruments, Ballaigues, Switzerland). The roots were randomly divided into two experimental groups $(n=24)$ according to irrigating solutions used during biomechanical preparation.

- NaOCl: root canal was irrigated with $5 \mathrm{~mL}$ of $1 \%$ sodium hypochlorite (Asfer Indústria Química Ltda., São Caetano do Sul, SP, Brazil) at every change of file.

- GEN: root canal was filled with 20\% glycolic ginger extract (Apis Flora ${ }^{\circledR}$, Ribeirão Preto, SP, Brazil) (9) during instrumentation and irrigated with $5 \mathrm{~mL}$ of physiological saline solution (Equiplex Indústria Farmacêutica, Aparecida de Goiânia, GO, Brazil) at each change of file.

The working length for biomechanical preparation was established at $16 \mathrm{~mm}$ (17). All root canals were biomechanically prepared using the rotary system MTWO (VDW GmbH, München, Germany) series 701 files 10-25 and series 702 files $25-40$, both $25 \mathrm{~mm}$ through the length of the canals. Throughout the biomechanical preparation and at each instrument change, canal was irrigated with $2 \mathrm{~mL}$ irrigating substance, according to groups it belongs. After preparation, root was washed with $10 \mathrm{~mL}$ of physiological saline solution, to neutralize irrigant solution, filled with EDTA (Biodinâmica, lbiporã, PR, Brazil) for 3 min, followed by rinsing with $10 \mathrm{~mL}$ of physiological saline solution and drying with absorbent paper points (Dentsply Maillefer)
$(3,8)$. Using the lateral compaction technique, root was filled with gutta-percha points 50 taper (Tanari; Tanariman Indrustrial Ltda, Manaus AM, Brazil), FF and MF accessory points (Tanari; Tanariman) associated with sealer (AH Plus: Dentsply Maillefer). After complete filling of root canal, cones were cut and compacted vertically. The apical and cervical regions were sealed with wax (Lysanda Produtos Odontológicos, São Paulo, SP, Brazil) and root stored in relative humidity in saline solution for 7 days, at $37{ }^{\circ} \mathrm{C}$.

After this period, root canal sealing material was removed with Largo drill (Dentsply Maillefer). Each root canal was enlarged with a low-speed drill provided by the manufacturer (WhitePost; Dentsply), with the same diameter of glass-fiber post system. The post space was $12 \mathrm{~mm}$ in depth and $2.0 \mathrm{~mm}$ in diameter, resulting in 4.0 $\mathrm{mm}$ of apical sealing. Before cementation, the root canals were washed with deionized water and dried with air jet. The glass-fiber post was cleaned with ethanol, and dried with air jet. The prepared roots were randomly divided into 2 subgroups ( $n=12)$, according to resin cement technique (etch-and-rinse or self-etching).

For the Rely X ARC (etch-and-rinse technique), the root area for cementing the posts was etched with 37\% phosphoric acid (Condac 37; FGM, Joinville, SC, Brazil) for $15 \mathrm{~s}$, washed with air/water jet for $30 \mathrm{~s}$ and dried with paper points (Dentsply Maillefer). The adhesive system (Adper Single Bond 2, 3M ESPE, St Paul, MN, USA) was applied to the inner walls of the root dentin and light-cured $(750 \mathrm{~mW} /$ $\mathrm{cm}^{2}$, Emmiter $\mathrm{A}_{\text {; }}$ Guilin Woodpecker Medical Instrument Co., Guilin, China), for $20 \mathrm{~s}$. The cement pastes were mixed in accordance to the manufacturers' instructions and placed in the root canal using a lentulo spiral instrument (Denstsply Maillerfer). Post was simultaneously coated with the cement, excess cement was removed with an explorer and light cured (750 mW/cm2; Emmiter A, Guilin) for $40 \mathrm{~s}$ on the top surface.

For the Rely XU200 (self-etching technique), the pastes were mixed according to the manufacturers' instructions and applied directly through to the depth of the root canal. Post was coated with the resin cement and slowly seated in place. The cementation was performed under finger pressure maintained for $2 \mathrm{~min}$, excess cement was removed with an explorer, and the cement/post was light-cured $(750 \mathrm{~mW} /$ $\left.\mathrm{cm}^{2}\right)$ (Emmiter A, Guilin Woodpecker Medical Instrument Co., Guilin, China) for $40 \mathrm{~s}$ on top surface.

\section{Push-Out Bond Strength Test}

Samples were stored for $48 \mathrm{~h}$ and then fixed onto an acrylic holder using dental wax and sectioned using a low-speed laboratory cutting machine (Labcut 1010, Extec Technologies Inc., Enfield, CT, USA) under water cooling. The samples were sectioned $(1.0 \pm 0.3 \mathrm{~mm}$ thick) perpendicularly 
to the long axis from each root: 4 slices in the coronal third and 3 slices in the middle third. The first slice in coronal third was discarded to avoid imperfections in the adhesive interface because of the presence of oxygen. Thickness of each slice was carefully verified using a digital caliper (Otto-Arminger \&t Cia Ltda., Brusque, SC, Brazil). Then, all samples were stored in physiologic saline at $37^{\circ} \mathrm{C}$ and 100\% relative humidity for 7 days.

The slices were identified on the coronal surface (larger diameter) of each sample and placed downward. For pushout test, a metallic cylinder induced a load in an apical to coronal direction on the post without applying any pressure to the dentin. Push-out tests were performed using a universal testing machine (EMIC DL-1000, Equipamentose Sistemas Ltda., São José dos Pinhais, PR, Brazil), at crosshead speed of $1 \mathrm{~mm} / \mathrm{min}$ and using $50 \mathrm{kgf}$ load cell (2).

\section{Failure Mode Analysis}

Samples were stained in hematoxylin solution for $3 \mathrm{~min}$, rinsed and dried with air jet to evaluate the dental structure. The samples were analyzed on stereomicroscope (Stemi 2000, Carls Zeiss NTS GmBH, Oberkochen, Germany) using 10x of magnification in order to determine the debonded failure mode: 1) adhesive failure between the luting agent and the dentin surface; 2 ) adhesive failure between the luting agent and the post; 3 ) cohesive failure in dentin; 4) cohesive failure in luting agent; 5) mixed failure (17).

\section{Scanning Electron Microscopy Evaluation (SEM)}

To illustrate the experimental conditions, two samples from each group were prepared for bond interface analysis on scanning electron microscope (JMS 5310, Jeol Brasil Instrumentos Científicos Ltda., São Paulo, SP, Brazil), using 2000x and 5000x of magnification.

\section{Statistical Analysis}

Data were submitted to statistical analysis using the computer software Statistica for Windows (Statsoft, Tulsa, OK, USA). The inferential statistics consisted of three-way

Table 1. Tukey test with mean $( \pm$ standard-deviation) of MPa values for the irrigant $\mathrm{x}$ resin cement interaction

\begin{tabular}{lcc}
\hline Irrigant & Resin Cement & Mean $( \pm$ SD $)$ \\
\hline $\mathrm{NaOCl}$ & ARC & $2.73 \pm 0.17^{\mathrm{A}}$ \\
$\mathrm{GEN}$ & $\mathrm{U} 200$ & $2.01 \pm 0.17^{\mathrm{B}}$ \\
$\mathrm{GEN}$ & $\mathrm{ARC}$ & $1.93 \pm 0.12^{\mathrm{B}}$ \\
$\mathrm{NaOCl}$ & $\mathrm{U} 200$ & $1.59 \pm 0.15^{\mathrm{B}}$ \\
\hline
\end{tabular}

Means followed by the same letter did not show statistically significant differences.
ANOVA (irrigant, resin cement, root third), followed by Tukey's test. The level of significance was set at 5\%.

\section{Results}

\section{Push-Out Bond Strength}

According to three-way ANOVA, irrigant ( $p=0.1396)$, interaction of irrigant and root third $(p=0.8457)$ and interaction among irrigant, resin cement and root third ( $p=0.8504)$ did not show significant differences on pushout bond strength.

Resin cement $(p=0.0003)$ showed differences statistically significant, being the $\mathrm{U} 200(1.80 \pm 0.12) \mathrm{B}$ with lower bond strength than ARC $(2.34 \pm 0.11) \mathrm{A}$. In relation to root third ( $p=0.0001)$, the cervical third $(2.62 \pm 0.12)$ A has statistically greater bond strength than the middle third $(1.51 \pm 0.09)$ B. Also, the interaction of irrigant and resin cement $(p=0.0001)$ and the interaction resin cement and root third $(p=0.0090)$ showed statistically significant differences. These differences for interaction factors are shown in Tables 1 and 2.

In Table 1, for the interaction of irrigant and resin cement, significant differences were observed between $\mathrm{ARC}(2.73 \pm 0.17) \mathrm{A}$ and $\mathrm{U} 200(1.59 \pm 0.15) \mathrm{B}$ in $\mathrm{NaOCl}$ irrigant group, fact not detected in the GEN group (homogeneous groups). Table 2 presents the interaction between resin cement and root third, in which statistically differences between ARC (1.97 \pm 0.14$) B$ and U200 $(1.07 \pm 0.08) C$ in the middle third were observed; on the other hand, no difference was observed between resin cements at the cervical third.

Regarding failure modes, it can be observed a prevalence of adhesives and mixed failures.

\section{SEM Observation}

Figure 1 presented the luting pattern according to the irrigant protocols for cervical third. There is a greater presence of resin tags when used ARC cement, while U200 groups showed a smoother morphology. In relation to the irrigants, $\mathrm{GEN}$ and $\mathrm{NaOCl}$ groups were similar

Table 2. Tukey test with mean ( \pm standard-deviation) of MPa values for the resin cement $\mathrm{x}$ root third interaction

\begin{tabular}{lll}
\hline Resin Cement & Third & Mean $( \pm$ SD $)$ \\
\hline ARC & Cervical & $2.69 \pm 0.16^{\mathrm{A}}$ \\
U200 & Cervical & $2.54 \pm 0.17^{\mathrm{A}}$ \\
ARC & Middle & $1.97 \pm 0.14^{\mathrm{B}}$ \\
U200 & Middle & $1.07 \pm 0.08^{\mathrm{C}}$ \\
\hline
\end{tabular}

Means followed by the same letter did not show statistically significant differences. 
morphologically.

Figure 2 shows SEM analysis in the middle third of the root. Note the formation of smaller resin tags compared to the cervical third. When used ARC cement, there is a greater amount of tags on adhesive interface. Besides, the adhesive interface using U200 showed some cracks, which may suggest depth could have interfered in the material adhesion. Regarding the irrigants, $\mathrm{GEN}$ and $\mathrm{NaOCl}$ groups were morphological similar.

\section{Discussion}

This study aimed to evaluate the bond strength of resin cements in root canals prepared with two irrigating solutions: ginger extract and sodium hypochlorite. Also,
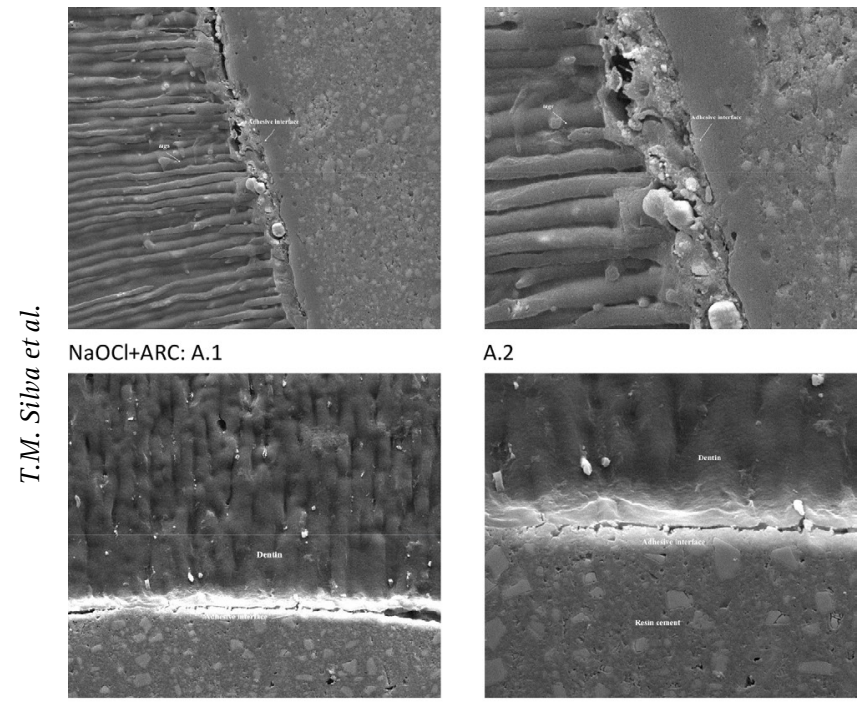

A. 2

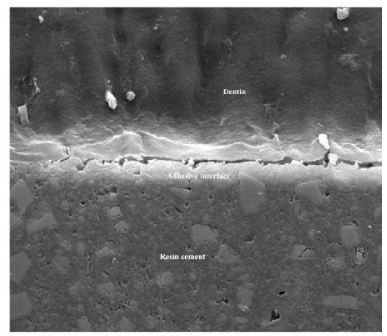

$\mathrm{NaOCl}+\mathrm{U} 200$ : B.1

B. 2

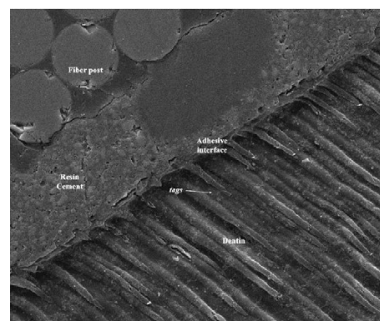

GEN+ARC: C.1

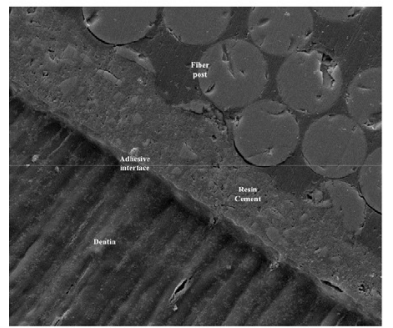

GEN+U200: D.1

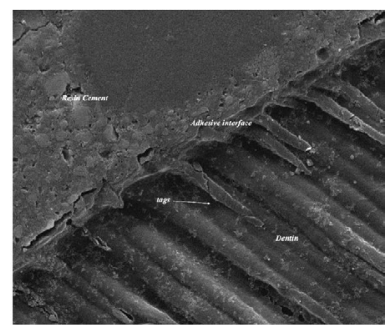

C. 2

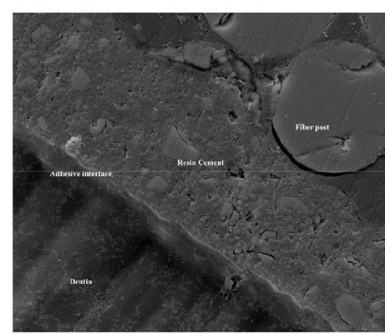

D.2

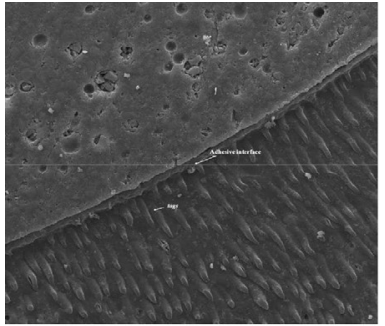

$\mathrm{NaOCl}+\mathrm{ARC}: \mathrm{A} .1$

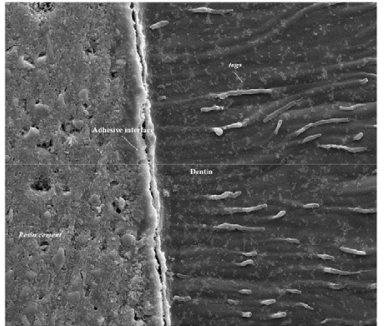

NaOCl+U200: B.1

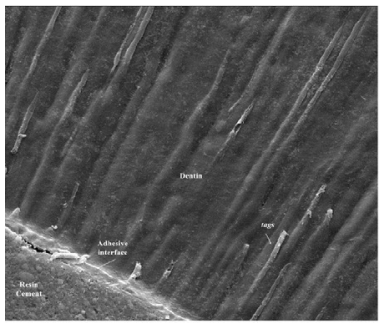

GEN+ARC: C.1

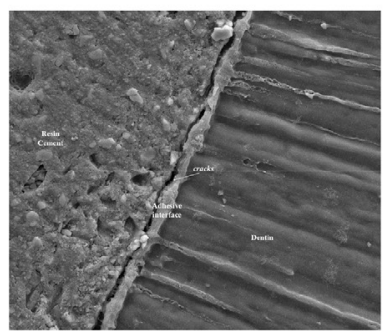

GEN+U200: D.1

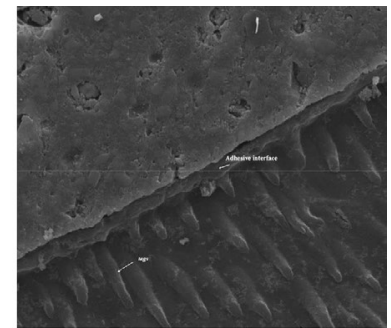

A. 2

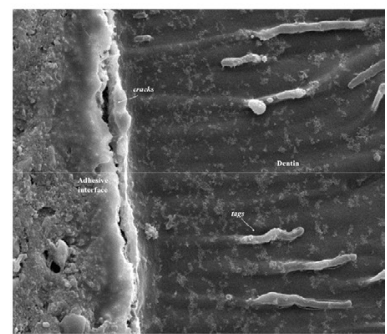

B. 2

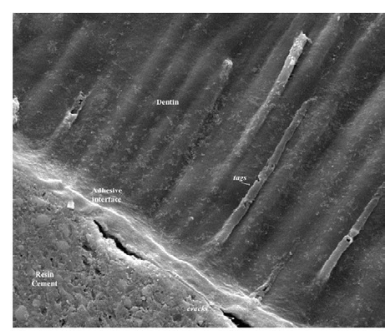

C. 2

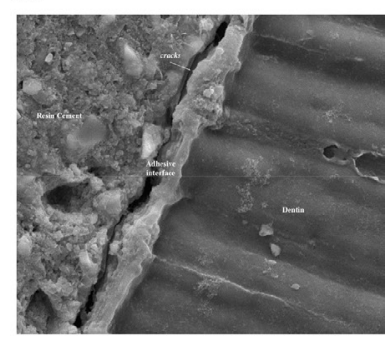

D.2

Figure 1. Representative SEM micrographs of cervical third: A: $\mathrm{NaOCl}+$ ARC group (A.1: $\times 2000$, A.2: $\times 5000)$; $: \mathrm{NaOCl}+\mathrm{U} 200$ group (B. $1: \times 2000$, B. $2: \times 5000)$; C: GEN+ARC group (C. $1-\times 2000$, C. $2: \times 5000)$; D: GEN+U200 group (D.1: $\times 2000$, D.2: $\times 5000)$.

Figure 2. Representative SEM micrographs of middle third: A: $\mathrm{NaOCl}+$ ARC group (A.1: $\times 2000$, A.2: $\times 5000)$; $\mathrm{B}: \mathrm{NaOCl}+\mathrm{U} 200$ group (B.1: $\times 2000$, B. $2: \times 5000)$; C: GEN+ARC group (C. $1: \times 2000$, C. $2: \times 5000)$; D: GEN+U200 group (D.1: $\times 2000$, D.2: $\times 5000)$. 
association with resin cements used in root canal preparation, sodium hypochlorite presented statistically significant differences between the types of resin cements. For $\mathrm{NaOCl}, \mathrm{ARC}$ cement had higher bond strength values than U200 self-etching resin cement. This difference may be correlated to surface treatment performed previously cementation. ARC (etch-and-rinse resin cement) is recommended pretreatment of dentin surface with etching, followed by adhesive system and resin cement. The etchand-rinse etching technique enables formation of hybrid layer, as described by Nakabayashi et al. (18), favoring the restorative materials bonding to dentin. $0 n$ the other hand, etching before cementation is not necessary for U200 (selfetching resin cement). It presents methacrylate monomers containing acid groups, which promotes simultaneously dentin demineralization and infiltration of the adhesive, simplifying bonding procedures $(14,16)$. Replacement of phosphoric acid etching for acid monomers presents in self-etching luting agent promotes lower hybridization and weaker adhesion (16).

According to previous study (19), the lower of stability in the bond strength between dentin-resin monomers may be due to hydrolytic deterioration of the components of the dentin, attributed to endogenous proteolytic mechanism due to the activity of metalloproteinases (MMPs) (20). The MMPs are endogenous proteases that are zinc and calcium dependent present in the mineralized dentin. However, the total etching or acidic monomers of the self-etching can change these proteases, resulting in progressive loss of collagen hybrid layer over time (21).

Within the limitation of the luting technique used, the roots were etched treated (etch-and-rinse or self-etching) for further cementing. This may have promoted changes in the surface, interfering on interaction of the factors. Furthermore, $\mathrm{NaOCl}$ forms a layer of oxygen along dentin surface, leading to weakness in the adhesive interface (22). This layer may have been removed with acid etching, differing from self-etching condition. Therefore, when associated to the etch-and-rinse resin cement (ARC), $\mathrm{NaOCI}$ group showed the best results of push-out bond strength. And then, the second null hypothesis was rejected.

Ginger solution did not show significantly differences between ARC and U200 resin cements on push-out bond strength. This result suggests that Ginger acts in dentinal tubules and promotes changes that favor the adhesion pattern on dentin-cement interface. The real mechanism of action of the Ginger extract has not been elucidated in the literature. Further investigations of ginger extract would be necessary to elucidate the action of the ginger on smear layer and dentin substrate.

In agreement with the other study (22), this study showed that irrigating solutions can influence on the bond strength of glass-fiber posts regardless the type of resin cement used. This fact highlights the importance of irrigating solutions selection during biomechanical root preparation for the posterior adhesive restorative procedures.

Push-out test was conducted to analyze small area and a uniform stress distribution on the adhesive interface (2). The test enabled us to compare the bond strength values between the "slices" of cervical and middle root third. Then, according to our results, the cervical third had higher bond strength values than the middle third, when compared to resin cements. These results differ from previous studies $(17,23)$ that there were no differences among to the thirds. The differences may result from the comparative analysis between the cervical and middle third, since the apical third was not included in this study. The root canal remained with $4.0 \mathrm{~mm}$ of apical sealing, according to the post manufacturer instructions, preventing the analysis in apical third.

The bond strength at cervical third revealed no significant differences for both resin cement. It could be related to luting technique recommended by the manufacturer that required light-cured for $40 \mathrm{~s}$ after cementation and post insertion. So, all groups were cured, which did not differentiate the bond strength values. In contrast, the middle third showed a statistically significant difference between resin cements. A decrease on the bond strength in the middle third might be related to some remnant endodontic sealer after post-space preparation and varied densities and distribution of dentinal tubules due to the different region of the root canal (22).

In middle third, ARC presented better performance compared to U200. Although resinous self-etching cements present advantages such as convenience and reduced clinical time, failures can occur in the formation of hybrid layer. Light-curing accelerates the monomers degree of conversion and the $\mathrm{C}$-factor in the root canals maximizes the polymerization shrinkage stress of adhesive systems (2), which lead us to observe that the resin cement cannot infiltrate properly throughout the depth of root dentin due to insufficient time with immediate curing (16), thereby creating an area more susceptible to failures. According to studies by De Munck et al. (24), the high viscosity of the self-etching cement may affect the flow and wettability on dental substrate into root canals. This fact could explain the differences behavior between both resin cements and root third showed in our study.

As illustrated in Figure 2, there are more tags formed on the adhesive interface in ARC group, while U200 shows some cracks in adhesive interface. As argued above, the dentin treatments under type of etching promoted differences in the amount of demineralized dentin and exposure of dentinal tubules, which may have interfered directly on pattern of cementation. Bond strength may be related to 
uniform resin cement penetration than to the depth of penetration into demineralized dentin (25). The retention and sealing on root canal are improved if resin tags are able to firmly bond to dentinal tubules. Therefore, in this study, it could be observed that the depth of root canal and the material viscosity may have interfered with the pattern of resin cement adhesion and dentinal treatment proposed. Then, the third null hypothesis of this study was rejected.

Within the limitations of this study, the push-out results were obtained in the immediate period (after $48 \mathrm{~h}$ ) of cementation, which may have interfered the bond strength values between the resin cements due to the setting time. Thus, more longitudinally studies are needed to prove that glycolic ginger extract effects on adhesion of etch-andrinse and self-etching resin cements could be better than conventional biomechanical substance as it also improved bond strength.

Based on the methodology used, it can be concluded that: the cervical third, regardless the irrigant employed, and the association between $\mathrm{NaOCl}$ and $\mathrm{ARC}$ presented better adhesive performance.

\section{Resumo}

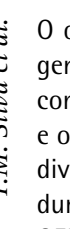

objetivo deste estudo foi avaliar in vitro a influência do extrato de gengibre 20\% na resistência adesiva de pinos de fibra de vidro cimentados com cimentos resinosos convencional ou autocondicionantes. Quarenta e oito raízes bovinas foram padronizadas $(17 \pm 0.5 \mathrm{~mm})$ e aleatoriamente divididas em dois grupos $(n=24)$, de acordo com o irrigante utilizado durante o preparo biomecânico: $\mathrm{NaOCl}$ : hipoclorito de sódio 1\%; e GEN: extrato glicólico de gengibre $20 \%$. Os canais radiculares foram preparados e aleatoriamente distribuidos em dois subgrupos $(n=12)$, conforme o protocolo de cimentação: autocondicionante (RelyX U200) e convencional (RelyX ARC). Após $48 \mathrm{~h}$, as raizes foram seccionadas perpendicularmente ( 4 no terço cervical e 3 no terço médio) e submetidas ao teste de resistência adesiva push-out ( $50 \mathrm{kgf}$ carga, $1.0 \mathrm{~mm} / \mathrm{min}$ ). 0 modo de falha foi analisado em MEV e estereomicroscopia. Os dados foram analisados pelos testes ANOVA 3 -fatores e Tukey $(p<0.05)$. ANOVA mostrou que não houve diferenças significativas entre U200 $(2.01 \pm 0.17)$ B e ARC (1.93 \pm 0.12$) B$ no grupo GEN, e no terço cervical para ambos os irrigantes $(2.69 \pm 0.16 \mathrm{~A}$ and $2.54 \pm 0.17 \mathrm{~A}$, respectivamente). 0 terço médio apresentou menor resistência adesiva que o terço cervical, independente do irrigante. Em geral, o terço cervical, independentemente do irrigante empregado, e a associação entre $\mathrm{NaOCl}$ e ARC apresentaram melhores desempenhos adesivos.

\section{References}

1. Zampronio CF, Sivieri-Araujo G, Bonetti-Filho I, Berbert FL. pH changes after manual or ultrasonic instrumentation and smear layer removal with EDTA or ultrasonic. Dent Traumatol 2008;24:542-545.

2. Baldissera R, Rosa RA, Wagner MH, Kuga MC, Grecca FS, Bodanezi A, et al.. Adhesion of Real Seal to human root dentin treated with different solutions. Braz Dent J 2012;23:521-526.

3. Valera MC, Maekawa LE, de Oliveira LD, Jorge AO, Shygei E, Carvalho CA. In vitro antimicrobial activity of auxiliary chemical substances and natural extracts on Candida albicans and Enterococcus faecalis in root canals. J Appl Oral Sci 2013;21:118-123.

4. Jain $P$, Ranjan $M$. Role of herbs in root canal irrigation - a review. Journal of Pharmacy and Biological Sciences 2014;9:6-10.

5. Ling $\mathrm{H}$, Yang $\mathrm{H}$, Tan SH, Chui WK, Chew EH. 6-Shogaol, an active constituent of ginger, inhibits breast cancer cell invasion by reducing matrix metalloproteinase-9 expression via blockade of nuclear factorkappa B activation. Br J Pharmacol 2010;161:1763-1777.

6. Koontongkaew S, Meesuk L, Aupaphong V, Ayudhaya TD, Poachanukoon 0. Inhibitory effect of Zingiber cassumunar extracts on lipopolysaccharideinduced cyclooxygenase- 2 and matrix metalloproteinase expression in human gingival fibroblasts. J Periodontal Res 2013;48:507-516.

7. Valera $\mathrm{MC}$, Cardoso FG, Maekawa $\mathrm{LE}$, Camargo $\mathrm{CH}$, de Oliveira LD, Carvalho CA. In vitro antimicrobial and anti-endotoxin action of Zingiber Officinale as auxiliary chemical and medicament combined to calcium hydroxide and chlorhexidine. Acta Odontol Scand 2015;73:556561.

8. Maekawa LE, Valera MC, Oliveira LD, Carvalho $\mathrm{CA}$, Camargo $\mathrm{CH}$, Jorge AO. Effect of Zingiber officinale and propolis on microorganisms and endotoxins in root canals. J Appl Oral Sci 2013;21:25-31.

9. Maekawa LE, Rossoni RD, Barbosa JO, Jorge AO, Junqueira JC, Valera MC. Different extracts of Zingiber officinale decrease Enterococcus faecalis infection in Galleria mellonella. Braz Dent J 2015;26:105-109.

10. Aziz TM, Anwar MN, El-Askary FS. Push-out bond strength of fiber posts to root canal dentin using a one-step self-etching adhesive: the effect of solvent removal and light-curing methods. J Adhes Dent 2014;16:79-86.

11. Heydecke G, Butz F, Strub JR. Fracture strength and survival rate of endodontically treated maxillary incisors with approximal cavities after restoration with different post and core systems: an in-vitro study. J Dent 2001;29:427-433.

12. Akkayan $B$, Gulmez T. Resistance to fracture of endodontically treated teeth restored with different post systems. J Prosthet Dent 2002;87:431437.

13. Nova V, Karygianni L, Altenburger MJ, Wolkewitz M, Kielbassa AM, Wrbas KT. Pull-out bond strength of a fibre-reinforced composite post system luted with self-adhesive resin cements. J Dent 2013;41:1020-1026.

14. Barcellos DC, Huhtala MFRL, Silva MA, Gomes APM, Franco LTF. Influence of adhesive system in bond strength of fiber glass posts to radicular dentin using dual cure resin cement. Braz Dent Sci 2014;17:4-10.

15. Piwowarczyk A, Bender R, Ottl P, Lauer HC. Long-term bond between dual-polymerizing cementing agents and human hard dental tissue. Dent Mater 2007;23:211-217.

16. Fernandes W, Jr., Rodrigues JR, da Silva JM, Pagani C, Souza RO. Bond strength of a self-adhesive resin cement to enamel and dentin. Int J Esthet Dent 2015;10:146-156.

17. de Araujo DF, Chaves LP, Bim 0, Jr., Pimentel Garcia FC, Ishikiriama SK, Honorio $\mathrm{HM}$, et al.. Influence of $2 \%$ chlorhexidine digluconate on bond strength of a glass-fibre post luted with resin or glass-ionomer based cement. J Dent 2014;42:735-741.

18. Nakabayashi N, Kojima K, Masuhara E. The promotion of adhesion by the infiltration of monomers into tooth substrates. J Biomed Mater Res 1982;16:265-273.

19. Cecchin D, Pin LC, Farina AP, Souza M, Vidal Cde M, Bello YD, et al.. Bond strength between fiber posts and root dentin treated with natural cross-linkers. J Endod 2015;41:1667-1671.

20. Pashley DH, Tay FR, Yiu C, Hashimoto M, Breschi L, Carvalho RM, et al.. Collagen degradation by host-derived enzymes during aging. J Dent Res 2004;83:216-221.

21. Seseogullari-Dirihan R, Apollonio F, Mazzoni A, Tjaderhane L, Pashley $D$, Breschi $L$, et al.. Use of crosslinkers to inactivate dentin MMPs. Dent Mater 2016;32:423-432.

22. Alkhudhairy Fl, Bin-Shuwaish MS. The effect of sodium hypochlorite and resin cement systems on push-out bond strength of cemented fiber posts. Pak J Med Sci 2016;32:905-910.

23. Leme $A A$, Coutinho $M$, Insaurralde $A F$, Scaffa $P M$, da Silva LM. The influence of time and cement type on push-out bond strength of fiber posts to root dentin. Oper Dent 2011;36:643-648.

24. De Munck J, Van Landuyt K, Peumans M, Poitevin A, Lambrechts P, Braem $M$, et al.. A critical review of the durability of adhesion to tooth tissue: methods and results. J Dent Res 2005;84:118-132.

25. Pashley DH, Carvalho RM. Dentine permeability and dentine adhesion. J Dent 1997;25:355-372. 